(2)

OPEN ACCESS

\title{
Effectiveness of community interventions for protecting and promoting the mental health of working-age adults experiencing financial uncertainty: a systematic review
}

\author{
Michael McGrath (D) ,'2 Fiona Duncan (D) , ${ }^{3}$ Kate Dotsikas (D), ${ }^{1}$ Cleo Baskin (D) , \\ Liam Crosby (1) , Shamini Gnani (1) , ${ }^{4}$ Rachael Maree Hunter, ${ }^{5}$ Eileen Kaner (i) , 6 \\ James Bowes Kirkbride (D) ,' Louise Lafortune (D) , ${ }^{7}$ Caroline Lee (D) , ${ }^{7,8}$ Emily Oliver, ${ }^{3}$ \\ David P Osborn (D) , 1,9 Kate R Walters (D) , Jennifer Dykxhoorn (D) , ${ }^{1,5}$ School for \\ Public Health Research Public Mental Health Programme
}

\begin{abstract}
- Additional supplemental material is published online only. To view, please visit the journal online (http://dx. doi.org/10.1136/jech-2020215574)
\end{abstract}

For numbered affiliations see end of article.

\section{Correspondence to} Dr Jennifer Dykxhoorn, Division of Psychiatry, University College London, London W1T 7NF, UK; j.dykxhoorn@ucl.ac.uk

Received 12 September 2020 Revised 1 March 2021 Accepted 23 March 2021

Published Online First 30 April 2021

\section{Check for updates}

(c) Author(s) (or their employer(s)) 2021. Re-use permitted under CC BY. Published by BMJ.

To cite: McGrath $\mathrm{M}$,

Duncan F, Dotsikas K, et al. J

Epidemiol Community Health 2021;75:665-673.

\begin{abstract}
Background The COVID-19 pandemic has created a period of global economic uncertainty. Financial strain, personal debt, recent job loss and housing insecurity are important risk factors for the mental health of working-age adults. Community interventions have the potential to attenuate the mental health impact of these stressors. We examined the effectiveness of community interventions for protecting and promoting the mental health of working-age adults in high-income countries during periods of financial insecurity.

Methods Eight electronic databases were systematically screened for experimental and observational studies published since 2000 measuring the effectiveness of community interventions on mental health outcomes. We included any non-clinical intervention that aimed to address the financial, employment, food or housing insecurity of participants. A review protocol was registered on the PROSPERO database (CRD42019156364) and results are reported in accordance with Preferred Reporting Items for Systematic Reviews and Meta-Analyses guidelines.
\end{abstract}

Results From 2326 studies screened, 15 met our inclusion criteria. Five categories of community intervention were identified: advice services colocated in healthcare settings; link worker social prescribing; telephone debt advice; food insecurity interventions; and active labour market programmes. In general, the evidence for effective and cost-effective community interventions delivered to individuals experiencing financial insecurity was lacking. From the small number of studies without a high risk of bias, there was some evidence that financial insecurity and associated mental health problems were amenable to change and differences by subpopulations were observed.

Conclusion There is a need for well-controlled studies and trials to better understand effective ingredients and to identify those interventions warranting wider implementation.

\section{INTRODUCTION}

The COVID-19 pandemic has created an unanticipated period of global financial insecurity. ${ }^{1}$ The introduction of measures to contain the virus and protect health systems has resulted in increased unemployment and job insecurity, ${ }^{2}$ personal debt, ${ }^{3}$ food insecurity ${ }^{4}$ and mortgage and rent stress, ${ }^{35}$ all of which are risk factors for poor mental health. ${ }^{6-10}$ Financial strain, indebtedness and the inability to provide materially for one's family may increase stress and household conflict, undermine personal autonomy and induce feelings of shame and guilt. ${ }^{11-13}$ Further, the transition out of secure housing and employment can disrupt structures that offer emotional stability, reduce social connectedness and remove the sense of purpose and fulfilment that employment can provide. ${ }^{11-14}$ As a result, periods of financial uncertainty are associated with the incidence of common mental disorders, ${ }^{15} 16$ increased symptoms of severe mental illness ${ }^{17}$ and suicide and self-harm. ${ }^{18}$

These relationships are bidirectional, reflecting both social causation and social drift. ${ }^{19}$ Adverse financial events increase the risk of developing mental illness (ie, social causation), ${ }^{14} 20$ and poor mental health can exacerbate financial insecurity due to experiences of stigma and discrimination, difficulties finding and maintaining employment and strained family and personal relationships (ie, social drift). ${ }^{14} 21$ Further, differentials in exposure and vulnerability across the socioeconomic gradient mean these stressors are concentrated in deprived communities and have the potential to widen inequalities. ${ }^{22}$ Longitudinal analysis of poverty dynamics in high-income countries shows that compared with a relatively small number of people experiencing sustained poverty, there is a substantially larger population moving in and out of poverty from 1 year to the next. ${ }^{23}$ Importantly, longer episodes of poverty are associated with a reduced likelihood of exiting poverty and a higher risk of re-entering poverty in the future. ${ }^{24}$ Therefore, periods of financial adversity represent a crucial juncture for preventing common mental disorders, promoting mental well-being and reducing social inequalities.

Community interventions present one means of attenuating the mental health impact of episodes of 
financial insecurity. ${ }^{25}$ These interventions draw on resources and expertise within communities and beyond the healthcare system to provide individuals with non-clinical forms of support to improve their psychosocial circumstances. ${ }^{26}$ By acknowledging that individuals are embedded within wider social, economic and political contexts, community interventions operate across all levels of the socioecological model of health promotion (from the individual to the policy level) to prioritise both health and social outcomes. ${ }^{26-29}$

While implementing interventions that act on the social determinants of mental health has been highlighted as a global priority, a substantial implementation gap exists. ${ }^{30} 31$ Barriers to wider implementation include limited evidence of effectiveness, the complexity of addressing social and economic challenges, and that action can be seen as inherently political. ${ }^{32}$ As the economic fallout of the COVID-19 pandemic unfolds, there have been renewed calls to pre-empt the mental health impacts of increasing household debt, unemployment and food insecurity by implementing interventions that provide social and financial support. ${ }^{33} 34$

Previous reviews have examined the effectiveness of community interventions for improving the mental health of specific subpopulations, such as the long-term unemployed, ${ }^{35}{ }^{36}$ people experiencing homelessness ${ }^{37} 38$ and people with pre-existing mental illness. ${ }^{39}{ }^{40}$ However, a stronger evidence base regarding the delivery of these interventions to the general population is required. A review of randomised controlled trials (RCT) of interventions aiming to reduce the impact of financial hardship on mental health found limited evidence of effectiveness for most types of interventions. ${ }^{41}$ All participants in the studies identified were unemployed, and the authors emphasised the need for further research and evaluation of interventions delivered in both primary care settings and within statutory and voluntary sector organisations. Therefore, we examine community interventions that seek to address acute financial stressors and their consequences (such as recent or imminent job loss, debt and legal issues, and housing and food insecurity) in a broader population and draw on evidence from a wider range of study designs. Specifically, this systematic review aims to (1) determine the effectiveness of community interventions for improving the mental health of working-age adults in high-income countries during periods of financial uncertainty, and (2) evaluate the impact of these interventions on health inequalities.

\section{METHODS}

We conducted a systematic review to identify effective community interventions for improved mental health and highlight priorities for future research. A review protocol was registered on the PROSPERO database (CRD 42019156364) and results are reported in accordance with Preferred Reporting Items for Systematic Reviews and Meta-Analyses guidelines. ${ }^{42}$

\section{Search strategy and screening}

An electronic search of eight academic and grey literature databases (Embase, Medline, PsycINFO, Web of Science, CINAHL Plus, the Cochrane Library, OpenGrey, Social Care Online) was conducted in August 2019. The search strategy incorporated a mix of keywords, and subject headings adapted for each database. Based on our study aims, the search strategy was built around three concepts: (1) personal or household financial insecurity, including recent unemployment, precarious employment, personal debt, food and housing insecurity; (2) community interventions; and (3) mental health and well-being outcomes (see

\begin{tabular}{|c|c|}
\hline \multicolumn{2}{|l|}{ Population } \\
\hline Include & $\begin{array}{l}\text { Working-age adults (18-64 years) living in high-income, OECD } \\
\text { countries experiencing periods of personal or household financial } \\
\text { uncertainty relating to employment (eg, recent or imminent } \\
\text { unemployment, precarious employment), personal debt and legal } \\
\text { issues, housing security (eg, mortgage or rent stress, threatened } \\
\text { eviction) or food insecurity. }\end{array}$ \\
\hline Exclude & $\begin{array}{l}\text { Other chronic stressors or populations with more complex needs (eg, } \\
\text { long-term homelessness, refugees and asylum seekers, recently released } \\
\text { offenders, people experiencing domestic violence). }\end{array}$ \\
\hline \multicolumn{2}{|l|}{ Intervention } \\
\hline Include & $\begin{array}{l}\text { Community or social interventions. Defined as any non-clinical } \\
\text { programme, service or policy that draws on resources beyond the } \\
\text { healthcare system to improve the psychosocial living conditions of } \\
\text { participants or their community. }\end{array}$ \\
\hline Exclude & Clinical or pharmaceutical interventions, including psychotherapies. \\
\hline \multicolumn{2}{|l|}{ Comparator } \\
\hline Include & $\begin{array}{l}\text { Experimental or quantitative observational studies that employ either } \\
\text { preintervention and postintervention measurements, or intervention } \\
\text { and control arms. }\end{array}$ \\
\hline Exclude & $\begin{array}{l}\text { Studies without preintervention and postintervention measurements } \\
\text { or a comparison group, formative and process evaluations, qualitative } \\
\text { studies. }\end{array}$ \\
\hline \multicolumn{2}{|l|}{ Outcomes } \\
\hline Primary outcomes & $\begin{array}{l}\text { Mental health outcomes broadly defined to include any objective } \\
\text { measure of: } \\
\text { Psychological distress (eg, worry, stress, shame). } \\
\text { The symptoms of common mental disorders (eg, anxiety, } \\
\text { depression). } \\
\text { Well-being and positive affect (eg, quality of life, happiness, self- } \\
\text { esteem, resilience). } \\
\text { Mental health service utilisation (eg, consultations, referrals, } \\
\text { prescribing). }\end{array}$ \\
\hline $\begin{array}{l}\text { Secondary } \\
\text { outcomes }\end{array}$ & $\begin{array}{l}\text { Any data relevant to the cost-effectiveness of the intervention (from an } \\
\text { individual, societal or government perspective). }\end{array}$ \\
\hline
\end{tabular}

OECD, Organisation for Economic Co-operation and Development.

online supplemental material). Two reviewers independently screened titles, abstracts and full-text articles, with discrepancies reconciled through discussion. Only studies reporting primary research and published in English since January 2000 were included. Additional studies were identified by manually searching relevant systematic reviews and study protocols identified during screening and backward-forward citation searching all studies meeting our inclusion criteria.

\section{Inclusion and exclusion criteria}

For inclusion, studies needed to report the effectiveness of a community intervention on mental health outcomes for working-age adults (aged 18-64) in high-income countries, as defined by the Organisation for Economic Co-operation and Development ${ }^{43}$ experiencing personal or household financial uncertainty (table 1). We draw on an established definition of community interventions and include non-clinical programmes, services and policies that (1) operate at any level of health promotion (from the individual level to the policy level), (2) draw on resources and expertise found within communities and beyond the healthcare system, and (3) address both health and social outcomes. ${ }^{26}{ }^{28} \mathrm{We}$ included interventions adopting universal or selective prevention strategies, which attempt to attenuate the impact of financial insecurity on mental health and well-being in the general population, rather than in people with existing mental health problems. ${ }^{44}$ Interventions were included if they addressed acute episodes of financial insecurity and their consequences, such as programmes for the recently unemployed (defined as a period of 
less than 12 months) or those at risk of homelessness, the provision of legal or debt advice, or services for the food insecure, rather than those addressing persistent problems such as longterm unemployment or homelessness.

The primary outcome, mental health and well-being, was broadly defined to include psychological distress, the symptoms of common mental disorders, aspects of well-being and positive affect, and mental health service utilisation. In order to measure effectiveness, only quantitative studies employing experimental, quasiexperimental or observational designs (with either a nonexposed comparison group or before-after intervention measurement) were included. Data relevant to an economic evaluation were extracted as secondary outcomes.

\section{Data extraction and analysis}

A data extraction framework was adapted from the Template for Intervention Description and Replication checklist ${ }^{45}$ and included the following elements: study location, participant characteristics, intervention description, financial stressor targeted, procedure and activities, mode/location of delivery, duration, frequency/intensity of intervention, study design, sample size, follow-up period and primary and secondary outcomes.

Two reviewers independently assessed individual study quality and risk of bias using the Effective Public Health Practice Project's Quality Assessment Tool for Quantitative Studies. ${ }^{46}$ Mental health outcomes of each study were assessed on a three-point scale and against eight domains: selection bias, study design, confounders, blinding, data collection methods, withdrawals, intervention integrity and analysis. Discrepancies were resolved through discussion, and each study was given an overall quality rating of 'high', 'moderate' or 'low', following instrument scoring guidelines. Studies were not excluded based on their quality assessment.

\section{RESULTS}

2326 non-duplicate titles identified were identified, 2304 from database searches and 22 from manual searches. Of these, 15 studies met our inclusion criteria (figure 1). Ten studies (67\%) were identified from the UK, two (13\%) from the USA and one study each (7\%) from Finland, Germany and Canada. Four studies used experimental research designs (three RCTs ${ }^{47-49}$ and one quasiexperimental controlled study ${ }^{50}$ ) and the remaining 11 employed either controlled or uncontrolled before-after methods. Based on our quality assessment, three studies were rated 'moderate' quality ${ }^{47450}$ and the remaining 12 studies 'low' quality.

Most studies $(n=12)$ measured mental health outcomes using standardised screening instruments for the symptoms of anxiety and depression, stress, psychological distress, well-being and functioning (table 2). Four studies reported mental health service utilisation, including primary care consultations, referrals, and antidepressant, hypnotic and anxiolytic prescribing. ${ }^{4750-52}$

\section{Community interventions}

Following data extraction, the included studies were categorised by the two reviewers into five intervention types: welfare and advice services colocated in healthcare settings $(n=7),{ }^{50} 52-57$ link worker social prescribing $(n=2),{ }^{47}{ }^{51}$ telephone debt advice $(\mathrm{n}=2),{ }^{48} 58$ active labour market programmes for the recently unemployed $(\mathrm{n}=3)^{49} 5960$ and food insecurity interventions $(\mathrm{n}=1)^{61}$ (table 3$)$.

Welfare and advice service colocated in healthcare settings Seven studies measured the effectiveness of colocated welfare and advice services on mental health outcomes. A quasiexperimental controlled study in London rated of moderate quality reduced self-reported financial strain among participants at 3-month follow-up, compared with controls. ${ }^{50}$ Overall, participants showed no changes in well-being, the symptoms of common mental disorders or self-reported general practice (GP) consultations. However, well-being scores did improve for those participants for whom advice resulted in positive financial outcomes, while symptoms of common mental disorders declined for women and Black participants.

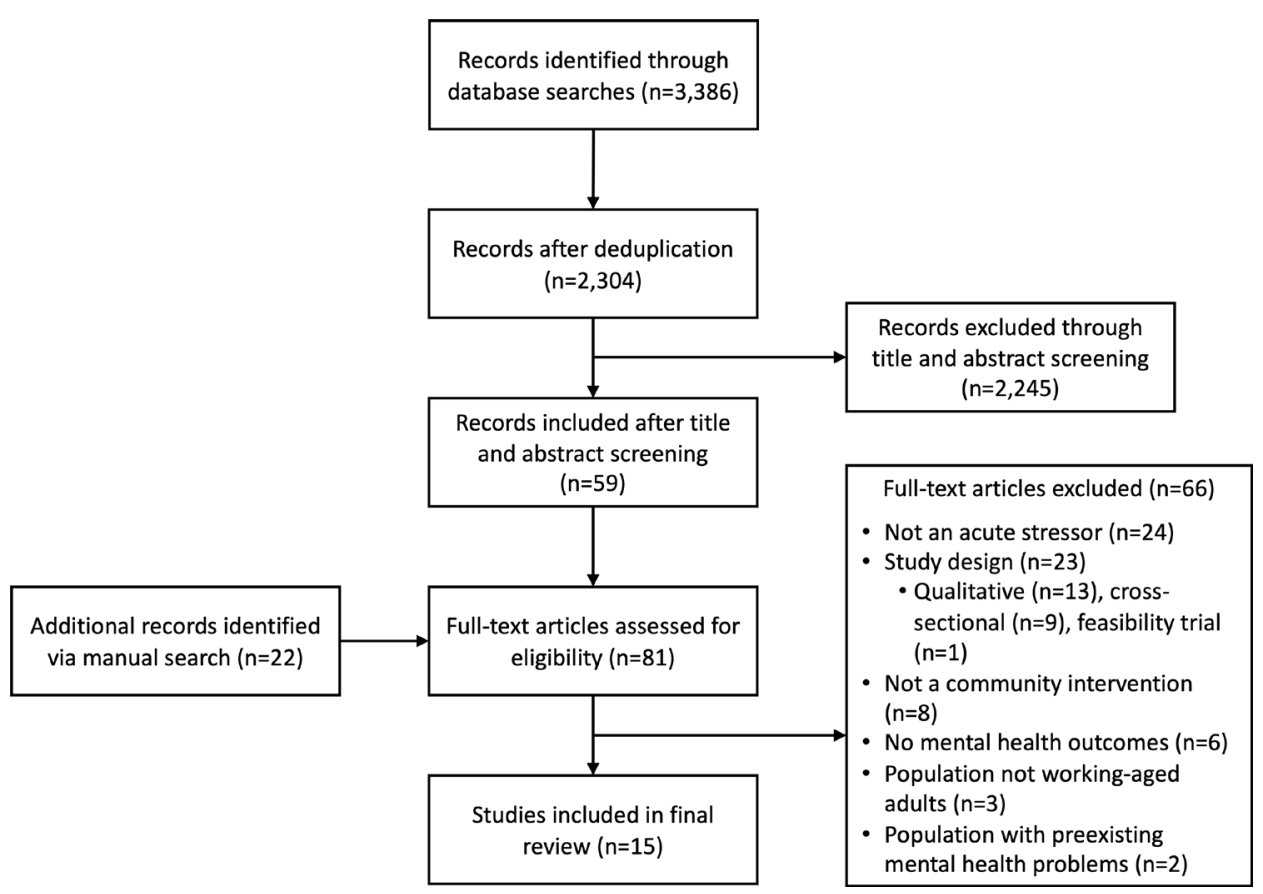

Figure 1 Preferred Reporting Items for Systematic Reviews and Meta-Analyses (PRISMA) flow diagram of included studies. 
Table 2 Summary of included studies

\begin{tabular}{|c|c|c|c|}
\hline Study (year) & Participants and setting & Study design & Outcomes \\
\hline \multicolumn{4}{|c|}{ Welfare and advice services located in healthcare settings } \\
\hline Abbott and Hobby $(2000)^{53}$ & $\begin{array}{l}\text { Service users ( } n=68,60 \% \text { female) in five general practices in a } \\
\text { deprived area of Liverpool, England. }\end{array}$ & $\begin{array}{l}\text { Uncontrolled before-after study } \\
\text { ( } 6 \text { and } 12 \text {-month follow-up) }\end{array}$ & SF-36 \\
\hline Caiels and Thurston $(2005)^{56}$ & $\begin{array}{l}\text { Participants ( } n=96,64 \% \text { female, } 98 \% \text { White) in an advice service } \\
\text { delivered at general practices in England. }\end{array}$ & $\begin{array}{l}\text { Uncontrolled before-after study } \\
\text { (follow-up at case closure) }\end{array}$ & SF-12 \\
\hline Abbott et al $(2006)^{54}$ & $\begin{array}{l}\text { Welfare benefits advice delivered to service users ( } n=345,53 \% \\
\text { female, } 96 \% \text { White British) recruited from } 59 \text { GP surgeries in England. }\end{array}$ & $\begin{array}{l}\text { Uncontrolled before-after study } \\
\text { ( } 6 \text { and } 12 \text {-month follow-up) }\end{array}$ & SF-36 \\
\hline Ryan et al $(2012)^{55}$ & $\begin{array}{l}\text { A medical-legal partnership for low-income earning patients ( } n=204 \text {, } \\
72 \% \text { female, } 53 \% \text { White) in a family clinic in Arizona, USA. }\end{array}$ & $\begin{array}{l}\text { Uncontrolled before-after study } \\
\text { (follow-up at case closure, mean: } 2 \text { months) }\end{array}$ & PSS-10, MYCaW \\
\hline Harris $(2013)^{57}$ & $\begin{array}{l}\text { Participants in an advice service delivered in a hospital in London } \\
\text { ( } n=745,66 \% \text { female, } 51 \% \text { White). }\end{array}$ & $\begin{array}{l}\text { Uncontrolled before-after study } \\
\text { (follow-up at case closure) }\end{array}$ & SF-36, health service costs \\
\hline Krska et al $(2013)^{52}$ & $\begin{array}{l}\text { Patients ( } n=148,65 \% \text { female, } 78 \% \text { working age) at six general } \\
\text { practices in deprived areas of England participating in an outreach } \\
\text { service. }\end{array}$ & $\begin{array}{l}\text { Uncontrolled before-after study (6-month } \\
\text { follow-up) }\end{array}$ & Health service utilisation \\
\hline Woodhead et al $(2017)^{50}$ & $\begin{array}{l}\text { Adults ( } n=910,63 \% \text { female, } 49 \% \text { White British) accessing colocated } \\
\text { welfare advice in eight general practices in London. }\end{array}$ & $\begin{array}{l}\text { Quasiexperimental controlled study (3-month } \\
\text { follow-up) }\end{array}$ & GHQ-12, SWEMWBS, health service utilisation \\
\hline \multicolumn{4}{|l|}{ Link worker social prescribing } \\
\hline Grant et al $(2000)^{47}$ & $\begin{array}{l}\text { Patients ( } n=161,75 \% \text { female) in } 26 \text { general practices in England } \\
\text { identified by their general practitioners (GPs) as having psychosocial } \\
\text { problems and referred to local and national voluntary organisations. }\end{array}$ & $\begin{array}{l}\text { Randomised controlled trial (1 and 4-month } \\
\text { follow-up) }\end{array}$ & HADS, Duke-UNC FSSQ, health service utilisation \\
\hline Grayer et al $(2008)^{51}$ & $\begin{array}{l}\text { Link workers direct patients ( } n=108,62 \% \text { female, mean age: } 43 \text {, } \\
67 \% \text { White) identified as having psychosocial problems in } 13 \text { general } \\
\text { practices in London to community and voluntary services. }\end{array}$ & $\begin{array}{l}\text { Uncontrolled before-after study } \\
\text { (3-month follow-up) }\end{array}$ & GHQ-12, CORE-OM, health service utilisation \\
\hline \multicolumn{4}{|l|}{ Telephone debt advice services } \\
\hline Jinhee Kim et al $(2013)^{58}$ & $\begin{array}{l}\text { Clients ( } n=355,68 \% \text { female, } 65 \% \text { White) drawn from the database of } \\
\text { a non-profit credit counselling agency in the USA. }\end{array}$ & $\begin{array}{l}\text { Controlled before-after study } \\
\text { (18-month follow-up) }\end{array}$ & $\begin{array}{l}\text { Composite health score, including experiences } \\
\text { of stress }\end{array}$ \\
\hline Pleasence and Balmer $(2007)^{48}$ & $\begin{array}{l}\text { People }(n=402) \text { experiencing problems with debt recruited from } 16 \\
\text { unemployment and welfare centres in England and Wales. }\end{array}$ & Randomised controlled trial (5-month follow-up) & STAI-S, EQ-5D \\
\hline \multicolumn{4}{|l|}{ Food insecurity interventions } \\
\hline Roncarolo et al (2016) $)^{61}$ & $\begin{array}{l}\text { Food insecure individuals ( } n=824,58 \% \text { female, } 36 \% \text { foreign born) } \\
\text { recruited from } 24 \text { non-profit organisations in Montreal, Canada. }\end{array}$ & $\begin{array}{l}\text { Controlled before-after study (9-month follow- } \\
\text { up) }\end{array}$ & SF-12 \\
\hline \multicolumn{4}{|l|}{ Active labour market programmes } \\
\hline Vinokur et al $(2000)^{49}$ & $\begin{array}{l}\text { Recently unemployed people ( } 55 \% \text { female, median age: } 35,76 \% \\
\text { White, mean period of unemployment: } 4.1 \text { weeks) in Michigan, USA, } \\
\text { participating in a week-long, group job search workshop. }\end{array}$ & $\begin{array}{l}\text { Randomised controlled trial (2,6 and 24-month } \\
\text { follow-up) }\end{array}$ & $\mathrm{HSCL}, \mathrm{UM}-\mathrm{CIDI}$, role and emotional functioning \\
\hline Saloniemi et al (2014) ${ }^{60}$ & $\begin{array}{l}\text { Recently unemployed people ( } n=342,53 \% \text { female, mean age: } \\
36,71 \% \text { unemployed for }<12 \text { months) in Finland participating in } \\
\text { government-run vocational training courses. }\end{array}$ & $\begin{array}{l}\text { Uncontrolled before-after study. } \\
\text { Follow-up at programme conclusion (range: } \\
3-24 \text { months) }\end{array}$ & GHQ-12, SSS, self-reported sense of coherence \\
\hline Rose $(2019)^{59}$ & $\begin{array}{l}9 \% \text { random sample of all people aged } 16-54 \text { entering unemployment } \\
\text { in Germany in } 1 \text { year. }\end{array}$ & $\begin{array}{l}\text { Controlled before-after study (12-month } \\
\text { follow-up) }\end{array}$ & Self-reported life satisfaction \\
\hline
\end{tabular}

CORE-OM, Core Outcome Measurement tools; Duke-UNC FSSQ, Functional Social Support Questionnaire; EQ-5D, EuroQol-5 Dimension; GHQ-12, General Health Questionnaire; HADS, Hospital Anxiety and Depression Scale; HSCL, Hopkins Symptoms Checklist; MYCaW, Measure Yourself Concerns and Well-being; PSS-10, Perceived Stress Scale; rOR, Ratio of odds ratios; SF-12, 12-item Short Form Survey; SF-36, 36-item Short Form Survey; SSS, Stress Symptom Scale; STAI-S, State-Trait Anxiety Inventory-state short form; SWEMWBS, Shortened Warwick-Edinburgh Mental Well-Being Scale; UM-CIDI, Composite International Diagnostic Interview, University of Michigan short version.

A further six uncontrolled before-after studies, which were assessed to be of low quality, showed inconsistent results. ${ }^{52-57}$ Reduced stress and increased well-being were observed among low-income earning, legal advice recipients in a family practice in Arizona, USA. ${ }^{55}$ Three studies in England reported improvements in some, but not all, 36-item Short Form Survey domains for welfare and financial advice recipients. ${ }^{535457}$ However, there was little evidence these improvements were sustained in the

Table 3 Types of community interventions identified

\begin{tabular}{ll}
\hline Type of intervention & Description \\
\hline $\begin{array}{l}\text { Welfare and advice services } \\
\text { colocated in healthcare settings } \\
(\mathrm{n}=7)^{50} 52-57\end{array}$ & $\begin{array}{l}\text { Services operating in primary care and hospital settings that provide information, support and advocacy for people dealing with financial insecurity. These } \\
\text { services assist participants with problems relating to welfare (eg, benefits entitlement and appeals), housing (eg, tenancy agreements, repossessions and } \\
\text { eviction), employment problems (eg, redundancy, unfair dismissal and training), finances (eg, income maximisation and financial literacy) and legal issues } \\
\text { (eg, debt, compensation and court action). }\end{array}$ \\
$\begin{array}{ll}\text { Link worker social prescribing } \\
(\mathrm{n}=2)^{4751}\end{array}$ & $\begin{array}{l}\text { Trained link workers refer patients who present to their general practitioner with psychosocial problems to voluntary and community sector services, } \\
\text { including cultural activities, befriending services and physical activity groups. }\end{array}$ \\
$\begin{array}{l}\text { Telephone debt advice services } \\
(\mathrm{n}=2)^{4858}\end{array}$ & $\begin{array}{l}\text { Advice delivered via telephone providing financial planning and budgeting, credit counselling, assistance with repossession and bailiffs, and referral } \\
\text { services, in conjunction with self-help material delivered online or by post. }\end{array}$ \\
$\begin{array}{l}\text { Active labour market programmes } \\
(\mathrm{n}=3)^{49} 5960\end{array}$ & $\begin{array}{l}\text { Programmes delivered as part of national labour policies for the recently unemployed. These policies differ by country but involve early intervention } \\
\text { when people become unemployed and regular monitoring of activities based on principles of 'mutual obligation'. Unemployed people may be required } \\
\text { to undertake job-seeking activities, participate in vocational and life skills training, complete work placements or volunteer their time in order to receive } \\
\text { welfare benefits and avoid sanctions. }\end{array}$ \\
\hline $\begin{array}{l}\text { Food insecurity interventions } \\
(\mathrm{n}=1)^{61}\end{array}$ & \begin{tabular}{l} 
Programmes that aim to alleviate food insecurity, including food banks, collective kitchens and bulk-buying clubs. \\
\hline
\end{tabular} \\
\hline
\end{tabular}


longer term. Another advice outreach service in deprived areas of England reported reductions in GP appointments and prescriptions for hypnotics and anxiolytics but found no evidence of a change in antidepressant prescribing. ${ }^{52}$

\section{Link worker social prescribing}

Two studies from the UK measured the effectiveness of link workers providing referral from primary care to voluntary and community sector organisations. Both studies focused on the mechanism of referral rather than the specific social prescription that patients received. An RCT in England used trained project facilitators to encourage participation in programmes managed by local and national voluntary organisations. ${ }^{47}$ The study failed to report all quality assessment domains adequately and received a moderate quality assessment. Compared with controls, at 4-month follow-up, participants in the intervention arm showed greater improvements in anxiety and functional health status. No difference was observed in depression or perceived social support. These patients also received more mental health prescriptions and fewer mental health referrals than controls. In an uncontrolled before-after study in London rated low quality, link workers directed, and if necessary, accompanied GP-referred patients to community programmes. ${ }^{51}$ At 3-month follow-up participants showed reductions in psychological distress, primary care consultations or mental health prescriptions.

\section{Telephone debt advice services}

Two studies describing telephone debt advice services were identified, and both received a low-quality rating. ${ }^{48} 62$ An RCT in England and Wales recruited individuals experiencing debtrelated stress from unemployment centres. ${ }^{48}$ Participants in the intervention arm received telephone advice, which included assistance with repossession and bailiffs, financial planning, written self-help material and a referral service. The trial encountered difficulties recruiting participants and delivering telephone advice and, because of higher than anticipated attrition, stopped before completing 12-month follow-up. However, at 20 weeks, there was no evidence of improved anxiety or general health scores. A not-for-profit debt management programme in the USA provided telephone credit counselling and online material. ${ }^{58}$ In a before-after evaluation of the programme, at 18-month follow-up participants reported small improvements in a composite health score, which included self-reported stress.

\section{Food insecurity interventions}

A non-randomised study of food insecure, low-income households in Canada was rated low quality and compared traditional food banks to 'alternative' food insecurity interventions (collective kitchens, bulk-buying clubs and community gardens), which aim to promote empowerment, social inclusion and skill development. ${ }^{61}$ Improvements in food security and mental health were observed in food bank users at 9-month follow-up, but not for participants of alternative interventions.

\section{Active labour market programmes for the recently unemployed}

Three studies examined mental health outcomes following participation in active labour market programmes. ${ }^{49} 5960$ An RCT in the USA assigned recently unemployed people into either week-long, job search workshops or a control group receiving an advice booklet. ${ }^{49}$ The intervention comprised daily 4-hour group sessions, which aimed to increase participants' sense of mastery and motivation by teaching job search skills and protecting against setbacks. At 2-year follow-up, participants in the intervention arm had lower depression scores, higher levels of role and emotional functioning, and were less likely to have experienced a major depressive episode in the previous year. The study received a moderate rating as not all quality assessment domains were reported.

Another two programmes for the recently unemployed were identified and received low-quality assessments. In Germany, participants in labour schemes who received wage and selfemployment subsidies or undertook training courses showed increased life satisfaction at 12-month follow-up, compared with baseline (measured within 2 weeks of becoming unemployed). ${ }^{59}$ At the conclusion of vocational training programmes in Finland, no improvements were observed in participants' psychological distress, stress symptom scores or sense of coherence, compared with baseline. ${ }^{60}$ Nevertheless, subgroup analyses revealed improvements in these outcomes for people with a tertiary education, those studying courses in 'white-collar' occupations, but not for those studying 'blue-collar' occupations.

\section{Economic evaluation}

A full economic evaluation was not conducted in any of the studies meeting our inclusion criteria. Nevertheless, five studies measured the impact of services on healthcare staffing, appointments and prescribing, ${ }^{4750-5257}$ three studies calculated financial returns to participants 5056 and one study reported the cost of delivering the service ${ }^{47}$ (table 4 ).

Interviews with healthcare workers revealed a perception that colocated welfare and advice services reduced staff workloads ${ }^{57}$ and the number of GP appointments, mental health referrals and prescriptions. ${ }^{52}$ However, changes to the frequency of GP consultations were not confirmed using either retrospective analysis of medical records ${ }^{52}$ or patient self-report. ${ }^{50}$ Colocated welfare advice services produced substantial financial gains for participants due to increased welfare payments and reduced debt. ${ }^{505657}$ A return on investment analysis of one service showed a total financial gain to participants of $£ 15$ for every $£ 1$ spent by the service provider after 8 months. ${ }^{50}$ A link worker service found that participants received more mental health prescriptions and fewer mental health referrals. ${ }^{47}$ However, the intervention arm accrued a higher mean cost per participant compared with controls after the cost of delivering the service was taken into account.

\section{DISCUSSION}

This review identified five categories of community interventions for working-age adults during periods of financial adversity. None of the included studies received a high-quality assessment and we find insufficient evidence to conclude that any one of these diverse categories of interventions is effective for improving mental health and well-being. Further, none of the studies identified conducted a full economic evaluation and there is limited evidence of an impact on costs to the health system.

Three studies without a high risk of bias showed some evidence of effectiveness. ${ }^{47} 4950$ Participation in group job skills training reduced the symptoms of depression and enhanced emotional functioning, ${ }^{49}$ which aligns with the wider literature confirming the effectiveness of similar job search programmes on the mental health of the long-term unemployed. ${ }^{6364}$ There was some evidence that the provision of legal and welfare advice in primary care ${ }^{50}$ and referral to community sector programmes ${ }^{47}$ improved outcomes, at least for some subpopulations. The remaining studies received low-quality assessment ratings, 
Table 4 Effectiveness of interventions on primary and secondary outcomes

\begin{tabular}{|c|c|c|}
\hline Study (year) & $\begin{array}{l}\text { Quality } \\
\text { rating }\end{array}$ & Effect on mental health outcomes \\
\hline \multicolumn{3}{|c|}{ Welfare and advice services located in healthcare settings } \\
\hline Abbott and Hobby $(2000)^{53}$ & Low & $\begin{array}{l}\text { For participants with increased income after } 6 \text { months }(n=48) \text {, improved mean scores for some SF- } 36 \text { domains: vitality (pre: } 20.8, \text { post: } 28.5, t=3.3, p=0.002) \text {, } \\
\text { emotional role functioning (pre: } 36.8 \text {, post: } 51.4, t=2.2, p=0.037) \text { and mental health (pre: } 45.9, \text { post: } 53.1, t=2.9, p=0.005) \text {, but not social functioning (pre: } \\
29.4 \text {, post: } 32.0, p>0.05 \text { ). No improvements observed at } 6 \text { months in participants without increased income }(n=20) \text {, or in either group after } 12 \text { months. }\end{array}$ \\
\hline Caiels and Thurston $(2005)^{56}$ & Low & $\begin{array}{l}\text { For those participants who complete preintervention and postintervention questionnaires }(n=81) \text {, no change in SF-12 score (pre: mean=34.1, post: } \\
\text { mean=35.6, } p=0.335 \text { ). Over the } 12 \text {-month period, } £ 356754 \text { gained on behalf of clients. }\end{array}$ \\
\hline Abbott et al $(2006)^{54}$ & Low & $\begin{array}{l}\text { At 6-month follow-up, no improvements in SF-36 domains (vitality, social functioning, emotional role and mental health) among those who saw an increase in } \\
\text { income following participation }(n=160) \text { compared with those who did not }(n=84) \text {. At } 12 \text {-month follow-up, improvements observed in emotional role (adjusted } \\
\text { mean difference: } 16.37(2.72-30.01), p=0.02) \text { and mental health (adjusted mean difference: } 6.85(0.72-12.98), p=0.03) \text { for participants with increased } \\
\text { income ( } n=134) \text {, compared with those who did not ( } n=50) \text {. No change in vitality and social functioning scores between the two groups. }\end{array}$ \\
\hline Harris $(2013)^{57}$ & Low & $\begin{array}{l}\text { Improvements in mean emotional well-being scores (preadvice: } 47.8 \text {, postadvice: } 61.3, t=3.3, p=0.001 \text { ) and role limitation due to emotional problems } \\
\text { (preadvice: } 35.1 \text {, postadvice: } 62.2, t=3.2, p=0.002 \text { ) observed at case closure }(n=65) .35 \% \text { of participants achieved financial gains during the programme } \\
\text { (mean gain } \mathrm{f} 4686 \text { per benefiting client). } 17 \text { weeks of staff time saved over the } 3 \text {-year study period, resulting in an annual savings of } £ 8700 \text {. }\end{array}$ \\
\hline Ryan et al $(2012)^{55}$ & Low & $\begin{array}{l}\text { Compared with baseline, participants ( } n=67 \text { ) reported decreased stress (mean difference: } 8.1, p<0.001 \text { ) and increased well-being (mean difference: } 1.8 \text {, } \\
p<0.001 \text { ) after participation in the programme. }\end{array}$ \\
\hline Krska et al $(2013)^{52}$ & Low & $\begin{array}{l}\text { In the 6-month period following participation, no changes observed in mean number of primary care mental health appointments, mental health referrals or } \\
\text { antidepressant prescriptions per patient. However, a decrease was observed in mean prescriptions for hypnotics/anxiolytics per patient }(-0.16, p<0.05) \text {. }\end{array}$ \\
\hline Woodhead et al $(2017)^{50}$ & Moderate & $\begin{array}{l}\text { Overall, no evidence of effect on probable common mental disorder or well-being. However, relative to controls, probable common mental disorder reduced for } \\
\text { female ( } \mathrm{rOR}=0.37(95 \% \mathrm{Cl} 0.20 \text { to } 0.70) \text { ) and Black advice recipients ( } \mathrm{rOR}=0.09(95 \% \mathrm{Cl} 0.03 \text { to } 0.28) \text { ). Well-being increased for participants who received a } \\
\text { positive outcome from the advice service ( } \beta \text { coefficient }=1.29,95 \% \mathrm{Cl} 0.25 \text { to } 2.32, \mathrm{p}=0.015) \text {. } \\
\text { No evidence that the intervention impacted 3-month, self-reported consultation frequency. } £ 2689 \text { average financial gain per participant over the study period. } \\
£ 15 \text { income gain per } € 1 \text { provided by the funder. }\end{array}$ \\
\hline \multicolumn{3}{|l|}{ Link worker social prescribing } \\
\hline Grant et al $(2000)^{47}$ & Moderate & $\begin{array}{l}\text { After adjustment for baseline scores, participants showed greater reductions in anxiety scores }(-1.9,95 \% \mathrm{Cl}-3.0 \text { to }-0.7, \mathrm{p}=0.002) \text {, but not depression } \\
\text { scores }(-0.9,95 \% \mathrm{Cl}-1.9 \text { to } 0.2, \mathrm{p}=0.116) \text {. Participants showed greater improvement in functional health components relating to pain }(-0.5,95 \% \mathrm{Cl}-0.8 \\
\text { to }-0.1, \mathrm{p}=0.005) \text {, emotional feelings }(-0.5,95 \% \mathrm{Cl}-0.8 \text { to }-0.2, \mathrm{p}=0.003) \text {, ability to carry out everyday activities }(-0.5,95 \% \mathrm{Cl}-0.8 \text { to }-0.2, \mathrm{p}=0.001) \text { and } \\
\text { feelings about general health }(-0.4,95 \% \mathrm{Cl}-0.7 \text { to }-0.1, \mathrm{p}=0.003) \text {. No difference was observed between groups in social support. }\end{array}$ \\
\hline Grayer et al (2008) $)^{51}$ & Low & $\begin{array}{l}\text { Compared with baseline, fewer participants experiencing psychological distress based on both the GHQ-12 (pre: } 82.6 \% \text {, post: } 52.2 \% \text {, difference: } 30.4 \% \\
\text { (16.9-43.9)) and the CORE-OM (pre: } 85.1 \% \text {, post: } 67.6 \text {, difference: } 17.5 \%(7.4 \%-27.7 \%)) \text {. The proportion of patients prescribed psychotropic medication } \\
\text { declined (pre: } 34.7, \text { post: } 18.8 \% \text {, difference: } 15.8 \%(6.0-25.6)) \text {, while the proportion receiving onward mental health referrals increased (pre: } 7.9 \% \text {, post: } \\
19.8 \% \text {, difference: } 11.9 \%(1.9-21.9)) \text {. }\end{array}$ \\
\hline \multicolumn{3}{|l|}{ Telephone debt advice services } \\
\hline Jinhee Kim et al (2013) ${ }^{58}$ & Low & $\begin{array}{l}\text { At 18-month follow-up, small improvements in health scores were observed in participants ( } n=70) \text { (pre: } 10.60, \text { post: } 10.98, t=2.62, p<0.05) \text { but not in controls } \\
(n=100) \text { (pre: } 10.68 \text {, post: } 10.60, t=0.29, p>0.05) \text {. }\end{array}$ \\
\hline Pleasence and Balmer $(2007)^{48}$ & Low & $\begin{array}{l}\text { Trial stopped early due to attrition. However, after } 20 \text { weeks, no changes were observed in anxiety or general health score for either the intervention group } \\
(n=119) \text { or the control group }(n=115) \text {. }\end{array}$ \\
\hline \multicolumn{3}{|l|}{ Food insecurity interventions } \\
\hline Roncarolo et al (2016) $)^{61}$ & Low & $\begin{array}{l}\text { Improved mental health scores were observed for participants in traditional food security interventions (pre: } 58.1 \text {, post: } 63.9 \text {, adjusted } \beta \text { coefficient: } 5.3 \\
(3.1-7.4) \text { ), while no changes were observed in participants of alternative interventions (pre: } 66.1 \text {, post: } 71.1 \text {, adjusted } \beta \text { coefficient: } 4.2 \text { (-1.3 to } 9.7) \text { ). }\end{array}$ \\
\hline \multicolumn{3}{|l|}{ Active labour market programmes } \\
\hline Rose $(2019)^{59}$ & Low & $\begin{array}{l}\text { Labour programmes that most closely replicate employment (wage subsidies and subsidised self-employment) had the largest effect on improving the well- } \\
\text { being of participants. When results were disaggregated by sex, no differences in well-being were observed participating in the ALMP schemes, compared with } \\
\text { non-participants. }\end{array}$ \\
\hline Saloniemi et al (2014) $)^{60}$ & Low & $\begin{array}{l}\text { Overall, no change in psychological distress, sense of coherence or stress at the end of the training course, compared with baseline. However, improvements in } \\
\text { all three measures were seen among participants with a tertiary education and those who were previously employed in a 'white-collar' occupation. }\end{array}$ \\
\hline Vinokur et al $(2000)^{49}$ & Moderate & $\begin{array}{l}\text { At 2-year follow-up, compared with controls, participants had significantly higher role functioning and lower depressive symptoms, and were less likely to } \\
\text { have experienced a probable major depressive episode. }\end{array}$ \\
\hline
\end{tabular}

CORE-OM, Core Outcome Measurement tools; GHQ-12, General Health Questionnaire; SF-12, 12-item Short Form Survey; SF-36, 36-item Short Form Survey.

primarily due to self-selected samples, ${ }^{53} 555758$ uncontrolled designs ${ }^{51-5760}$ and poor study retention. ${ }^{4853545861}$ Four studies used primary care and mental health service utilisation as outcome measures. ${ }^{4750-52}$ However, it is unclear whether these outcomes indicated improved access to services or quality of care, or declining mental health.

This overall lack of evidence mirrors the findings of reviews examining the effect on health and social outcomes of colocated advice services ${ }^{65}$ and social prescribing, ${ }^{66}$ and interventions to reduce the impact of poverty and inequality, ${ }^{67}$ and unemployment and economic hardship. ${ }^{41}$ Studies identified in our review described the challenges of conducting trials in populations experiencing financial uncertainty ${ }^{48}$ and within primary care and voluntary sector settings ${ }^{47}$ highlighting the difficulties of measuring the impact of community interventions using traditional effectiveness studies. ${ }^{6768}$
The studies we identified provide useful insights for intervening on health inequalities, which is particularly important in light of emerging evidence that the COVID-19 pandemic has exacerbated existing patterns of inequalities. ${ }^{69-71}$ Since the introduction of measures to contain the pandemic, those living in deprived communities and low-income households have been more likely to experience both financial adversity (employment sector shutdowns, reduced income and job losses) ${ }^{69} 70$ and declining mental health. ${ }^{71}$ Most interventions we identified aimed to reach deprived communities, either through targeted delivery in deprived neighbourhoods 50525356 or through eligibility based on income or employment status. ${ }^{4849555960}$ As might be expected, there was some evidence that mental health outcomes improved only for those participants who saw improvements in their financial circumstances. ${ }^{49} 50535461$ This indicates that the social determinants of health are amenable 
to change through focused community interventions and that reducing financial uncertainty could be an actionable pathway towards improved mental health.

Colocated welfare and advice services produced substantial financial gains for participants. ${ }^{505657}$ This underscores the capacity for these programmes to correct the historical underclaiming of welfare entitlements observed in many deprived communities, ${ }^{65}$ which has been highlighted as a persistent problem during the implementation of COVID-19 employment protection policies. ${ }^{72}$ Nevertheless, evidence from vocational training programmes showing psychological distress reduced only among participants previously employed in salaried professions or with a tertiary education warns of the potential for community interventions to widen health inequalities. ${ }^{60}$

There is some evidence that integrating community services into healthcare settings can improve mental health, ${ }^{4750}$ which is important within a policy context that increasingly emphasises third sector organisations' role in providing care. ${ }^{73}$ Nevertheless, all 13 studies that adequately reported sample characteristics recruited more female participants than males (range 52\%-75\%). As more than half of our studies recruited participants from GPs, this may in part reflect lower primary care consultation rates observed in men. ${ }^{74} 75$ Therefore, variation in service utilisation and quality of care by gender, age, economic deprivation and language and ethnicity ${ }^{76-78}$ should be considered when implementing programmes in these settings.

\section{Limitations}

A focus on universal and selective prevention during the acute stages of financial adversity means we have systematically excluded studies evaluating community interventions on specific subpopulations with recognised pre-existing challenges, such as the long-term unemployed and homeless, and people with severe

\section{What is already known on this subject}

- Episodes of financial adversity, such as recent job loss, precarious employment, personal debt and housing and food insecurity, represent a crucial period for the protection and promotion of mental health in working-age adults.

- Community interventions are one means through which to address these social determinants of mental health.

- A stronger evidence base regarding the effectiveness of community interventions delivered to the general population during periods of financial insecurity is required.

\section{What this study adds}

- The evidence base for effective and cost-effective community interventions is marked by the presence of small, uncontrolled studies including potentially non-representative samples.

- Nevertheless, job search programmes, welfare and advice services located in healthcare settings, and link worker referral services show some evidence of effectiveness, at least for some subpopulations.

- The social determinants of health are amenable to change through focused community interventions and mitigating the impact of financial adversities could be an actionable pathway towards improved mental health. mental illness. Similarly, we excluded a wider body of literature examining the effectiveness of interventions that seek to address chronic financial hardship and neighbourhood-level poverty. ${ }^{79} 80$ In general, the interventions we identified were not mental health interventions. Instead, their primary aim was to improve the material circumstances of participants. Therefore, we will have excluded studies evaluating the impact of these, and other promising interventions, on non-mental health outcomes, particularly those operating outside of healthcare settings where mental health outcomes are not routinely collected. We included only studies published since 2000 in order to identify evidence most relevant to contemporary service configuration and contexts; however, this may have introduced some bias. Reviewing studies from across high-income countries with divergent welfare provision models means the effect of an intervention observed in one country is unlikely to be generalisable to another ${ }^{81}$ Finally, excluding qualitative research and process evaluations further limits our findings. For many studies, limited information could be extracted regarding the intervention setting, the procedures and resources involved and any underpinning theory of change. A better understanding of the mechanisms through which these interventions act and the pathways towards improved mental health is required. ${ }^{82}$

\section{CONCLUSION}

The evidence base for community interventions delivered to individuals experiencing personal or household financial adversity was marked by the presence of small, uncontrolled studies drawn from self-selected samples. However, our review highlights that community interventions can successfully reduce financial uncertainty, which is increasingly important given the deteriorating economic situation caused by the COVID-19 pandemic.

\section{Author affiliations}

${ }^{1}$ Division of Psychiatry, University College London, London, UK

${ }^{2}$ Department of Health Services Research and Policy, London School of Hygiene \& Tropical Medicine, London, UK

${ }^{3}$ Department of Sport and Exercise Sciences, Durham University, Durham, UK ${ }^{4}$ Department of Primary Care and Public Health, Imperial College London, London, UK

${ }^{5}$ Department of Primary Care and Population Health, University College London, London, UK

${ }^{6}$ Institute of Health and Society, Newcastle University, Newcastle, UK ${ }^{7}$ Cambridge Public Health, University of Cambridge, Cambridge, UK

${ }^{8}$ Cambridge Institute for Sustainability Leadership, Cambridge, UK

${ }^{9}$ Camden and Islington NHS Foundation Trust, London, UK

Contributors DPO, EO and KRW were responsible for the study design. MM, FD and $K D$ performed the screening and quality assessment. MM conducted the data extraction and synthesis and wrote the initial draft. MM, FD, KD, CB, LC, JD, SG, $\mathrm{RMH}, \mathrm{EK}, \mathrm{JBK}, \mathrm{LL}, \mathrm{CL}, \mathrm{EO}, \mathrm{KRW}$ and DPO contributed to the interpretation of results, critically reviewed the manuscript and approved the final submission.

Funding This study was funded by the National Institute for Health Research (NIHR) School for Public Health Research (grant reference: BH154142). The NIHR School for Public Health Research is a partnership between the Universities of Sheffield, Bristol, Cambridge, Imperial; and University College London; the London School for Hygiene \& Tropical Medicine; LiLaC - a collaboration between the Universities of Liverpool and Lancaster; and Fuse - the Centre for Translational Research in Public Health, a collaboration between Newcastle, Durham, Northumbria, Sunderland and Teesside Universities. MM, JD, JBK and DPO are supported by the NIHR Biomedical Research Centre at University College London Hospitals. DPO is also supported by the NIHR Applied Research Collaboration North Thames. EK is supported by an NIHR Senior Investigator Award and the NIHR Applied Research Collaboration North East and North Cumbria.

Disclaimer The views expressed are those of the author(s) and not necessarily those of the NIHR or the Department of Health and Social Care.

Competing interests None declared. 
Patient consent for publication Not required.

Provenance and peer review Not commissioned; externally peer reviewed.

Supplemental material This content has been supplied by the author(s). It has not been vetted by BMJ Publishing Group Limited (BMJ) and may not have been peer-reviewed. Any opinions or recommendations discussed are solely those of the author(s) and are not endorsed by BMJ. BMJ disclaims all liability and responsibility arising from any reliance placed on the content. Where the content includes any translated material, BMJ does not warrant the accuracy and reliability of the translations (including but not limited to local regulations, clinical guidelines, terminology, drug names and drug dosages), and is not responsible for any error and/or omissions arising from translation and adaptation or otherwise.

Open access This is an open access article distributed in accordance with the Creative Commons Attribution 4.0 Unported (CC BY 4.0) license, which permits others to copy, redistribute, remix, transform and build upon this work for any purpose, provided the original work is properly cited, a link to the licence is given, and indication of whether changes were made. See: https://creativecommons.org/ licenses/by/4.0\%

\section{ORCID iDs}

Michael McGrath http://orcid.org/0000-0003-0465-176X

Fiona Duncan http://orcid.org/0000-0002-4929-5685

Kate Dotsikas http://orcid.org/0000-0001-5023-5201

Cleo Baskin http://orcid.org/0000-0001-6254-8707

Liam Crosby http://orcid.org/0000-0003-4643-3701

Shamini Gnani http://orcid.org/0000-0001-6246-9590

Eileen Kaner http://orcid.org/0000-0002-7169-9344

James Bowes Kirkbride http://orcid.org/0000-0003-3401-0824

Louise Lafortune http://orcid.org/0000-0002-9018-1217

Caroline Lee http://orcid.org/0000-0002-5730-4350

David P Osborn http://orcid.org/0000-0003-2519-1539

Kate R Walters http://orcid.org/0000-0003-2173-2430

Jennifer Dykxhoorn http://orcid.org/0000-0001-6391-8626

\section{REFERENCES}

1 McKee M, Stuckler D. If the world fails to protect the economy, COVID-19 will damage health not just now but also in the future. Nat Med 2020;26:640-2.

2 OECD. OECD employment outlook, 2020

3 Achou B, Boisclair D, d'Astous P, et al. Early impact of the COVID-19 pandemic on household finances in Quebec. Canadian Public Policy 2020:46:S217-35. doi:10.3138/cpp.2020-087

4 Loopstra R. Vulnerability to food insecurity since the COVID-19 lockdown. London: King's College London \& The Food Foundation, 2020.

5 Biddle N, Edwards B, Gray M, et al. COVID-19 and mortgage and rental payments: may 2020. Canberra: ANU Centre for Social Research and Methods, 2020.

6 Rönnblad T, Grönholm E, Jonsson J, et al. Precarious employment and mental health: a systematic review and meta-analysis of longitudinal studies. Scand I Work Environ Health 2019;45:429-43.

7 Kim TJ, von dem Knesebeck 0, insecurity Pjob. Perceived job insecurity, unemployment and depressive symptoms: a systematic review and meta-analysis of prospective observational studies. Int Arch Occup Environ Health 2016:89:561-73.

8 Richardson T, Elliott P, Roberts R. The relationship between personal unsecured debt and mental and physical health: a systematic review and meta-analysis. Clin Psychol Rev 2013;33:1148-62.

9 Maynard M, Andrade L, Packull-McCormick S, et al. Food insecurity and mental health among females in high-income countries. Int J Environ Res Public Health 2018;15. doi:10.3390/ijerph15071424. [Epub ahead of print: 06 Jul 2018].

10 Tsai AC. Home foreclosure, health, and mental health: a systematic review of individual, aggregate, and contextual associations. PLoS One 2015;10:e0123182.

11 Fitch C, Hamilton S, Bassett P, et al. The relationship between personal debt and mental health: a systematic review. Ment Health Rev J 2011;16:153-66.

12 McKee-Ryan F, Song Z, Wanberg CR, et al. Psychological and physical well-being during unemployment: a meta-analytic study. J Appl Psychol 2005;90:53-76.

13 Jones AD. Food insecurity and mental health status: a global analysis of 149 countries. Am J Prev Med 2017:53:264-73.

14 Olesen SC, Butterworth P, Leach LS, et al. Mental health affects future employment as job loss affects mental health: findings from a longitudinal population study. BMC Psychiatry 2013;13:144.

15 Laaksonen E, Martikainen P, Lahelma E, et al. Socioeconomic circumstances and common mental disorders among Finnish and British public sector employees: evidence from the Helsinki health study and the Whitehall II study. Int J Epidemiol 2007;36:776-86.

16 Meltzer $\mathrm{H}$, Bebbington $\mathrm{P}$, Brugha $\mathrm{T}$, et al. The relationship between personal debt and specific common mental disorders. Eur J Public Health 2013;23:108-13.

17 Saraceno B, Levav I, Kohn R. The public mental health significance of research on socio-economic factors in schizophrenia and major depression. World Psychiatry 2005;4:181-5.
18 Meltzer H, Bebbington P, Brugha T, et al. Personal debt and suicidal ideation. Psychol Med 2011:41:771-8.

19 Lund C. Poverty and mental health: a review of practice and policies. Neuropsychiatry 2012:2:213-9.

20 Loopstra R. Interventions to address household food insecurity in high-income countries. Proc Nutr Soc 2018;77:270-81.

21 Lund C, Stansfeld S, de Silva M. Social determinants of mental health. In: Patel V,

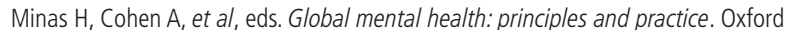
University Press, 2013

22 Patel V, Lund C, Hatherill S. Mental disorders: equity and social determinants. In: Blas E, Kurup AS, eds. Equity, social determinants and public health programmes. Geneva: World Health Organization, 2010.

23 Devicienti F. Poverty persistence in Britain: a multivariate analysis using the BHPS, 1991-1997: ISER working paper series, 2001.

24 Oxley $\mathrm{H}$, Thai-Thanh $\mathrm{D}$, Antolín P. Poverty dynamics in six OECD countries. OECD Economic Studies, 2000: 7-52.

25 World Health Organization. Social determinants of mental health. Geneva: World Health Organization, 2014.

26 Castillo EG, ljadi-Maghsoodi R, Shadravan S, et al. Community interventions to promote mental health and social equity. Curr Psychiatry Rep 2019;21:35.

27 McLeroy KR, Norton BL, Kegler MC, et al. Community-based interventions. American Public Health Association, 2003.

28 Anderson LM, Adeney KL, Shinn C, et al. Community coalition-driven interventions to reduce health disparities among racial and ethnic minority populations. Cochrane Database Syst Rev 2015;6:Cd009905

29 Nagy E, Moore S. Social interventions: an effective approach to reduce adult depression? J Affect Disord 2017;218:131-52.

30 Burgess RA, Jain S, Petersen I, et al. Social interventions: a new era for global mental health? Lancet Psychiatry 2020;7:118.

31 Campion J. Public mental health: key challenges and opportunities. BJPsych Int 2018;15:51-4

32 Johnson S. Social interventions in mental health: a call to action. Soc Psychiatry Psychiatr Epidemiol 2017;52:245-7.

33 Gunnell D, Appleby L, Arensman E, et al. Suicide risk and prevention during the COVID-19 pandemic. Lancet Psychiatry 2020;7:468-71.

34 Holmes EA, O'Connor RC, Perry VH, et al. Multidisciplinary research priorities for the COVID-19 pandemic: a call for action for mental health science. Lancet Psychiatry 2020;7:547-60.

35 Audhoe S, Hoving J, Sluiter J. Vocational interventions for unemployed: effects on work participation and mental distress; a systematic review. database of Abstracts of reviews of effects (Dare): quality-assessed reviews. York: Centre for Reviews and Dissemination, 2010.

36 Koopman MY, Pieterse ME, Bohlmeijer ET, et al. Mental health promoting interventions for the unemployed: a systematic review of applied techniques and effectiveness. International Journal of Mental Health Promotion 2017;19:202-23.

37 Baxter AJ, Tweed EJ, Katikireddi SV, et al. Effects of housing first approaches on health and well-being of adults who are homeless or at risk of homelessness: systematic review and meta-analysis of randomised controlled trials. J Epidemiol Community Health 2019;73:379-87.

38 Hwang SW, Tolomiczenko G, Kouyoumdjian FG, et al. Interventions to improve the health of the homeless: a systematic review. Am J Prev Med 2005;29:311-9.

39 Webber M, Fendt-Newlin M. A review of social participation interventions for people with mental health problems. Soc Psychiatry Psychiatr Epidemiol 2017;52:369-80.

40 Lloyd-Evans B, Mayo-Wilson E, Harrison B, et al. A systematic review and metaanalysis of randomised controlled trials of peer support for people with severe mental illness. BMC Psychiatry 2014;14:39.

41 Moore THM, Kapur N, Hawton K, et al. Interventions to reduce the impact of unemployment and economic hardship on mental health in the general population: a systematic review. Psychol Med 2017:47:1062-84.

42 Moher D, Liberati A, Tetzlaff J, et al. Preferred reporting items for systematic reviews and meta-analyses: the PRISMA statement. BMJ 2009;339:b2535.

43 Organisation for Economic Co-operation and Development. Country classification 2019, 2019.

44 World Health Organization. Prevention of Mental Disorders - Effective Interventions and Policy Options, 2004.

45 Hoffmann TC, Glasziou PP, Boutron I, et al. Better reporting of interventions: template for intervention description and replication (TIDieR) checklist and guide. BMJ 2014;348:g1687.

46 Effective Public Health Practice Project. Quality assessment tool for quantitative studies. Canada: Hamilton, 1998

47 Grant C, Goodenough T, Harvey I, et al. A randomised controlled trial and economic evaluation of a referrals facilitator between primary care and the voluntary sector. BMJ 2000;320:419-23.

48 Pleasence P, Balmer NJ. Changing fortunes: results from a randomized trial of the offer of debt advice in England and Wales. J Empir Leg Stud 2007;4:651-73.

49 Vinokur AD, Schul Y, Vuori J, et al. Two years after a job loss: long-term impact of the jobs program on reemployment and mental health. J Occup Health Psychol 2000;5:32-47. 
50 Woodhead C, Khondoker M, Lomas R, et al. Impact of co-located welfare advice in healthcare settings: prospective quasi-experimental controlled study. $\mathrm{Br} J$ Psychiatry 2017;211:388-95.

51 Grayer J, Cape J, Orpwood L, et al. Facilitating access to voluntary and community services for patients with psychosocial problems: a before-after evaluation. BMC Fam Pract 2008;9:27.

52 Krska J, Palmer S, Dalzell-Brown A, et al. Evaluation of welfare advice in primary care: effect on practice workload and prescribing for mental health. Prim Health Care Res Dev 2013;14:307-14.

53 Abbott S, Hobby L. Welfare benefits advice in primary care: evidence of improvements in health. Public Health 2000;114:324-7.

54 Abbott S, Hobby L, Cotter S. What is the impact on individual health of services in general practice settings which offer welfare benefits advice? Health Soc Care Community 2006;14:1-8.

55 Ryan AM, Kutob RM, Suther E, et al. Pilot study of impact of medical-legal partnership services on patients' perceived stress and wellbeing. J Health Care Poor Underserved 2012;23:1536-46.

56 Caiels J, Thurston M. Evaluation of the Warrington district cab GP outreach project, 2005

57 Harris H. Delivering welfare rights advice in the acute hospital setting. London: Health Protection Agency, 2013.

58 Kim J, Thomas Garman E. Relationships among credit counseling clients' financial well being, financial behaviors, financial stressor events, and health. J Financial Couns Plan 2013;14.

59 Rose D. The impact of active labour market policies on the well-being of the unemployed. J Eur Soc Policy 2019:29:396-410.

60 Saloniemi A, Romppainen K, Strandh M, et al. Training for the unemployed: differential effects in white- and blue-collar workers with respect to mental well-being. Work, Employment and Society 2014;28:533-50.

61 Roncarolo F, Bisset S, Potvin L. Short-Term effects of traditional and alternative community interventions to address food insecurity. PLoS One 2016;11:e0150250.

62 Kim TJ, von dem Knesebeck O. Is an insecure job better for health than having no job at all? A systematic review of studies investigating the health-related risks of both job insecurity and unemployment. BMC Public Health 2015;15:985.

63 Puig-Barrachina V, Giró P, Artazcoz L, et al. The impact of active labour market policies on health outcomes: a scoping review. Eur J Public Health 2020;30:36-42.

64 Coutts AP, Stuckler D, Cann DJ. The health and wellbeing effects of active labor market programs. Wellbeing, 2014: 1-18.

65 Adams J, White M, Moffatt $S$, et al. A systematic review of the health, social and financial impacts of welfare rights advice delivered in healthcare settings. BMC Public Health 2006;6:81.

66 Bickerdike L, Booth A, Wilson PM, et al. Social prescribing: less rhetoric and more reality. A systematic review of the evidence. BMJ Open 2017;7:e013384.
67 Wahlbeck K, Cresswell-Smith J, Haaramo P, et al. Interventions to mitigate the effects of poverty and inequality on mental health. Soc Psychiatry Psychiatr Epidemiol 2017;52:505-14.

68 Petticrew M, Cummins S, Ferrell C, et al. Natural experiments: an underused tool for public health? Public Health 2005;119:751-7.

69 Blundell R, Costa Dias M, Joyce R, et al. COVID-19 and Inequalities* . Fisc Stud 2020;41:291-319.

70 Wright L, Steptoe A, Fancourt D. Are we all in this together? longitudinal assessment of cumulative adversities by socioeconomic position in the first 3 weeks of lockdown in the UK. J Epidemiol Community Health 2020;74:683-8.

71 Kwong ASF, Pearson RM, Adams MJ, et al. Mental health before and during the COVID-19 pandemic in two longitudinal UK population cohorts. Br J Psychiatry 2020:1-10.

72 Ahmed F, Ahmed Na'eem, Pissarides C, et al. Why inequality could spread COVID-19. Lancet Public Health 2020;5:e240.

73 Drinkwater C, Wildman J, Moffatt S. Social prescribing. BMJ 2019;364:I1285.

74 Wang Y, Hunt K, Nazareth I, et al. Do men consult less than women? an analysis of routinely collected UK general practice data. BMJ Open 2013;3:e003320.

75 Schlichthorst M, Sanci LA, Pirkis J, et al. Why do men go to the doctor? sociodemographic and lifestyle factors associated with healthcare utilisation among a cohort of Australian men. BMC Public Health 2016;16:1028.

76 Burt J, Lloyd C, Campbell J, et al. Variations in GP-patient communication by ethnicity, age, and gender: evidence from a national primary care patient survey. Br J Gen Pract 2016;66:e47-52.

77 Mukhtar TK, Bankhead C, Stevens S, et al. Factors associated with consultation rates in general practice in England, 2013-2014: a cross-sectional study. Br J Gen Pract 2018:68:e370-7.

78 Campbell JL, Ramsay J, Green J, Age GJ. Age, gender, socioeconomic, and ethnic differences in patients' assessments of primary health care. Qual Health Care 2001;10:90-5.

79 Ludwig J, Duncan GJ, Gennetian LA, et al. Long-term neighborhood effects on low-income families: evidence from moving to opportunity. Am Econ Rev 2013;103:226-31.

80 Candy B, Cattell V, Clark C, et al. The health impact of policy interventions tackling the social determinants of common mental disorder: a systematic review. J Public Ment Health 2007:6:28-39.

81 Bambra C, Eikemo TA. Welfare state regimes, unemployment and health: a comparative study of the relationship between unemployment and self-reported health in 23 European countries. J Epidemio/ Community Health 2009;63:92-8.

82 Allmark P, Baxter S, Goyder $\mathrm{E}$, et al. Assessing the health benefits of advice services: using research evidence and logic model methods to explore complex pathways. Health Soc Care Community 2013;21:59-68.

83 Kluve J. The effectiveness of European active labor market policy. Bonn: Forschungsinstitut zur Zukunft der Arbeit, 2006. 